\title{
A Comparative Analysis of the Self-Leadership Behaviors of Thai and U.S. Elementary Teachers
}

\author{
Praporntip Kunagornpitak ${ }^{1}$, Wirot Sanrattana ${ }^{2} \&$ Merrill M. Oaks ${ }^{3}$ \\ ${ }^{1}$ Office of Graduate Studies, Udon Thani Rajabhat University, Thailand \\ ${ }^{2}$ Faculty of Education, Khon Kaen University, Thailand \\ ${ }^{3}$ College of Education, Washington State University, WA, USA \\ Correspondence: Praporntip Kunagornpitak, Office of Graduate Studies, Udon Thani Rajabhat University, \\ Thailand.
}

Received: February 12, 2019

Accepted: March 22, 2019 Online Published: June 29, 2019

doi:10.5539/ies.v12n7p93

URL: https://doi.org/10.5539/ies.v12n7p93

\begin{abstract}
The purpose of the study was to compare self-leadership behaviors of Thai and U.S. elementary teachers using the Revised Self-Leadership Questionnaire. Findings indicated that Thai and U.S. elementary teachers had self-leadership behaviors at a high level. Significant differences in self-leadership behaviors were found for Thai teachers regarding two demographic variables, and for U.S. teachers regarding four variables. The study identified strengths related to the cultures of each group of teachers that were seen as potential benefits to the other group. These strengths provided the basis for recommendations related to professional development and teacher training.
\end{abstract}

Keywords: comparative analysis, self-leadership behaviors, Thai elementary teachers, U.S. elementary teachers

\section{Introduction}

Katzenmeyer and Moller (2001), and Hilty (2011) highlighted teachers' potential ability to influence others toward improved educational practice. Similarly, Andrews and Crowther (2002) discussed teacher leadership as a behavior intended to positively influence school success through deliberate improvement of pedagogy. Within this framework, teacher leadership can be formal or informal. The broad activities in which teacher leaders engage are many and varied (Lord \& Miller, 2002; Silva, Gimbert, \& Nolan, 2000). A partial list would include serving as a coach or consultant to individual teachers, managing the curriculum, serving as department chair, developing curriculum or materials, mentoring new teachers, coordinating professional development, facilitating action research, managing the distribution of materials needed for teaching, and participating in decision making (Harris \& Muijs, 2005).

As these examples indicate, the teachers' self-leadership role can vary substantially from one location to another. One way to classify leadership work is to use a typology of leadership tasks that have been linked to improved student learning. Leadership development transforms individuals, teams, organizations, and society. (Center for Creative leader, 2019; Uchida, 2019) According to Leithwood and Riehl (2005), leaders engage in three kinds of activities that promote achievement. The first is setting direction that includes, but is not limited to, establishing a shared vision and fostering the acceptance of group goals. The second is changing the organization by strengthening the culture, modifying organizational processes, and changing structures. Finally, leaders can develop leadership by offering intellectual stimulation and offering individual support. Teacher leaders may engage in any of these activities, but they often engage in the latter by helping their colleagues improve their practice. These practice-improvement roles are the focus of this analysis. Those who have studied teacher leaders as a support for practice improvement seem to agree that the effectiveness of the role will depend in part on a variety of environmental factors, although exactly which ones deserve further clarification (Lord \& Miller, 2002; Smylie et al., 2002; York-Barr \& Duke, 2004). One way to conceptualize environments is to conduct a resource analysis, focusing primarily on financial or material, social, and human resources (Coleman, 1988; Gamoran, Anderson, Quiroz, Secada, Williams, \& Ashmann, 2003; Spillane \& Thompson, 1997)

Self-leadership is an enable process whereby a person learns to know him/herself better and through this better self-understanding is able to steer his/her life better (Joshi, 2019). Similarly, self-leadership is a term used to describe a comprehensive set of self-influence strategies that have recently demonstrated potential for application 
in today's organizations. Simply stated, self-leadership (Manz \& Neck, 2004; Manz \& Sims, 2001; Midlock, 2011) is a process through which people influence themselves to achieve the self-direction and self-motivation necessary to perform as leaders in the context of school responsibilities. Self-leadership strategies are often divided into three basic categories consisting of: 1) behavior-focused strategies, 2) natural reward strategies, and 3) constructive thought pattern strategies (Anderson \& Prussia, 1997; Manz \& Neck, 2004; Manz \& Sims, 2001; Prussia, Anderson, \& Manz, 1998).

Behavior-focused strategies involve the self-regulation of behavior through the use of self-assessment, self-reward, and self-discipline (Manz, 1986; Manz \& Neck, 2004; Manz \& Sims, 1980). These strategies are designed to foster positive desirable behaviors while discouraging ineffective behaviors. Behavior-focused strategies are particularly useful in managing behavior related to the accomplishment of necessary but unpleasant tasks.

Natural reward strategies involve seeking out work activities that are inherently enjoyable (Manz, 1986; Manz $\&$ Neck, 2004). This set of strategies also includes the focusing of attention on the more pleasant or gratifying aspects of a given job or task rather than on the unpleasant or difficult aspects. Finally, constructive thought pattern strategies involve the creation and maintenance of functional patterns of habitual thinking (Manz \& Neck, 2004; Neck \& Manz, 1992; Neck, Stewart, \& Manz, 1995). Specific thought- oriented strategies include the evaluation and challenging of irrational beliefs and assumptions, mental imagery of successful future performance, and positive self-talk. Usually leadership is viewed as an outward process involving the influence of formally designated leaders on followers.

Self-leadership is a self-influencing process through which people achieve the self-direction and self-motivation necessary to perform. The concept of self-leadership first emerged in the mid-1980s as an expansion of self-management, which was rooted in clinical self-control theory and inspired by Kerr and Jemier's notion of "substitutes for leadership" (Manz \& Neck, 2004).

Neck \& Houghton (2006) stated that over the past two decades, the self-leadership concept has enjoyed considerable popularity, as evidenced by the large number of practitioner-oriented self-leadership books and articles on the subject. Moreover, self-leadership has earned the respect of many academics, as reflected by the large number of theoretical and empirical self-leadership journal publications, and by coverage in a growing number of management and leadership textbooks. In addition, Neck \& Houghton (2006) pointed out that current trends in self-leadership research included intercultural/international issues, self-leadership contingency factors, executive health/fitness levels and shared leadership. Self-leadership has developed largely within the context of the culture of the USA, and the intercultural/international aspects of self-leadership have not been fully explored to date.

This cross-national research focused on the degree of expertise and potential benefits of self-leadership for elementary school teachers in Thailand and the United States according to the degree of self-leadership employed by elementary school teachers in both countries. Significant differences, if any, between the self-leadership of elementary teachers in Thailand and the United States were analyzed in terms of behavior-focused strategies, natural reward strategies, and constructive thought pattern strategies, and in terms of correlation between demographic variables and self-leadership behaviors of these two groups. The research proposed to provide new understanding of self-leadership behaviors of elementary school teachers in Thailand and the United States. Increased knowledge is fundamentally important as schools in both countries move toward increased school-based management and instruction. This is especially important in Thailand, where building self-leadership strengths of teachers has the potential to move the next phase of that country's educational reform movement forward more efficiently and expeditiously.

\subsection{Purpose of the Research}

In modern society self-leadership is increasingly important in contemporary educational and organizational management. Generation of this new body of knowledge is rooted in several related theories of self-influence including self-regulation, self-control, and self-management. Based on the first eleven years of the new century, education is increasingly becoming more internationalized, therefore this cross-national study proposed to provide new understanding of the influence of self-leadership strategies, the difference between the self-leadership strategies in terms of those three categories, and the level of relationship among selected demographic variables related to self-leadership strategies of elementary school teachers in Thailand and the United States.

Increased knowledge of the benchmarking of self-leadership strategies in Thailand and the United States is fundamentally important as schools in both countries move toward increased school-based management and instruction. Especially, building self-leadership strengths of teachers has the potential to move the next phase of the 
educational reform movement in Thailand forward more efficiently and expeditiously.

The purpose of this research was to 1) study the degree of self-leadership behaviors of Thai and U.S. elementary teachers, 2) compare self-leadership behaviors of Thai and U.S. elementary teachers regarding selected demographic variables, 3) compare self-leadership behaviors between Thai and U.S. elementary teachers, and 4) determine the correlation between demographic variables and self-leadership behaviors of Thai and U.S. elementary teachers.

\subsection{Research Hypotheses}

In this study, it was estimated that: 1) both Thai and U.S. elementary teachers possessed a high degree of self-leadership behaviors, 2) there were significant differences in self-leadership behaviors of Thai and U.S. elementary teachers regarding selected demographic variables, 3) Thai and U.S. elementary teachers were different in terms of the degree of self-leadership behaviors, and 4) all selected variables had a statistically significant correlation with self-leadership behaviors.

\section{Method}

This study used survey research methodology. The population consisted of 300,259 Thai public elementary teachers in academic year 2009 and 1,508,899 U.S. public elementary teachers in academic year 2010. Krejcie and Morgan's table was used to determine a sample of 395 Thai teachers and 398 U.S. teachers at a significant level of 0.05 classified by proportion of geographical regions. (Krejcie \& Morgan, 1970) Teachers were selected using multi-stage random sampling. Participants included one teacher in each randomly selected school.

The research instrument was "The Revised Self-Leadership Questionnaire" (RSLQ) introduced in 2002 by Houghton and Neck (2002). The dimensions of self-leadership were grouped under nine subscales and three self-leadership dimensions, including: 1) behavior-focused strategies (self-goal setting, self-reward, self-punishment, self-observation, and self-cueing), 2) natural reward strategies (focus thought on natural rewards), and 3) constructive thought strategies (visualizing successful performance, self-talk, and evaluating beliefs and assumptions). The questionnaire was translated from English to Thai language and validated for content accuracy by three research university experts in Educational Administration. The translated RSLQ was subsequently pre-tested for reliability with 30 respondents not included in the final sample. The total Cronbach's alpha coefficient of reliability (Revelle \& Zinbarg, 2009) was .758 and .611, .798, and .628 for behavior-focused strategies, natural reward strategies, and constructive thought strategies respectively.

For data collection in Thailand the researcher sent a consent form to participants by post. After following up three times, 375 questionnaires were returned, accounting for $95 \%$ of distributed questionnaires. For the United States, following review of the research process by Washington State University's Office for Human Research Protections for Human Subjects Assurance, the researcher sent an e-mail to each participating teacher with the survey document attached. After the first e-mail was sent, a subsequent follow-up was conducted by means of either a direct call or e-mail. For this group a total 366 questionnaires were returned, accounting for $92 \%$ of the distributed e-questionnaires. The SPSS program was employed to analyze the collected data to obtain frequency, percentage, means, standard deviation, and t-test.

\section{Results}

Hypothesis 1: It was estimated that both Thai and U.S. elementary teachers possessed a high degree of self-leadership behaviors.

According to Table 1, it was found that both Thai and U.S. elementary teachers possessed a high level of self-leadership behaviors in the level of overall, and in the level of dimension. That is in line with the stated hypothesis. The consideration of each subscale of each dimension for the Thai and U.S. elementary teachers found that, with one exception, every subscale was in the "high" level. Only the self-reward subscale of U.S. elementary teachers was "moderate extent" $(\bar{X}=3.01)$. It was noticed that the self-reward subscale of both Thai and U.S. elementary teachers were the lowest order. Results are presented in table 1 according to the following: any score that falls between 4.51-5.00 is term, Very High Extent (VHE), 3.51-4.50=High Extent (HE) 2.51-3.50=Moderate Extent (ME), 1.51-2.50=Low Extent (LE), and 0.00-1.50=Very Low Extent (VLE). 
Table 1. Mean $(\bar{X})$ and Standard Deviation (S.D.) rating for self-leadership behaviors of Thai and U.S. elementary teachers.

\begin{tabular}{lcccccc}
\hline \multirow{2}{*}{ Dimensions and subscales } & \multicolumn{3}{c}{ Thai elementary teachers } & \multicolumn{3}{c}{ U.S. elementary teachers } \\
\cline { 2 - 7 } & Mean & SD & Mean value & Mean & SD & Mean value \\
\hline Behavior-focused strategies & 3.93 & 0.50 & HE & 3.86 & 0.68 & HE \\
Self-goal setting & 4.00 & 0.50 & HE & 4.09 & 0.77 & HE \\
Self-reward & 3.61 & 0.97 & HE & 3.01 & 1.26 & ME \\
Self-observation & 4.18 & 0.46 & HE & 3.97 & 0.76 & HE \\
Self-cueing & 3.95 & 0.82 & HE & 4.34 & 0.94 & HE \\
Natural reward strategies & 4.17 & 0.46 & HE & 4.13 & 0.73 & HE \\
Focusing thoughts on natural reward & 4.17 & 0.46 & HE & 4.13 & 0.73 & HE \\
Constructive thought pattern strategies & 3.83 & 0.51 & HE & 3.83 & 0.78 & HE \\
Visualizing successful performance & 3.90 & 0.54 & HE & 3.65 & 0.96 & HE \\
Self-talk & 3.65 & 0.90 & HE & 3.87 & 1.03 & HE \\
Evaluating beliefs and assumptions & 3.93 & 0.51 & HE & 3.97 & 0.80 & HE \\
Overall & 3.95 & 0.41 & HE & 3.89 & 0.65 & HE \\
\hline
\end{tabular}

Hypothesis 2: It was estimated that there were significant differences in self-leadership behaviors of Thai and U.S. elementary teachers according to gender, age, highest degree, years of experience, school location, school size, geographical school region, and instructional level.

Data indicated that in the case of Thai elementary teachers, significant differences in the self-leadership behaviors of teachers were found at the level of 0.05 based on years of experience and school location, which correlated with the proposed hypothesis. Tables 2 and 3 clarify behaviors of self-leadership according to years of experience and school location, respectively.

Table 2. Summary of one-way ANOVA for years of experience related to self-leadership behaviors of Thai elementary teachers

\begin{tabular}{cccccccc}
\hline Years of experience & $\mathrm{N}$ & Mean & $\mathrm{SD}$ & $\mathrm{F}$ & d.f.1 & d.f.2 & Sig. \\
\hline 0-10 years & 48 & 4.03 & 0.40 & & & & \\
11-20 years & 75 & 3.85 & 0.35 & $3.185^{*}$ & 2 & 372 & 0.043 \\
> 20 years & 252 & 3.96 & 0.42 & & & & \\
\hline
\end{tabular}

*significant at the 0.05 level.

The Fisher's Least Significant Difference (LSD) Test indicated participants who had 0-10 years experience had self-leadership behaviors higher than those with11-20 years, and participants who had more than 20 years' experience had self-leadership behaviors higher than those with 11-20 years.

Table 3. Summary of one-way ANOVA for school location related to self-leadership behaviors of Thai elementary teachers

\begin{tabular}{cccccccc}
\hline School location & $\mathrm{N}$ & Mean & SD & F & d.f.1 & d.f.2 & Sig. \\
\hline Urban & 89 & 3.93 & 0.45 & & & & \\
Suburban & 113 & 4.03 & 0.37 & $3.68^{*}$ & 2 & 371 & 0.026 \\
Rural & 173 & 3.90 & 0.40 & & & & \\
\hline
\end{tabular}

*significant at the 0.05 level.

The Fisher's LSD Test indicated that participants who taught in suburban locations had self-leadership behaviors higher than rural participants.

In the case of U.S. elementary teachers, significant differences in the self-leadership behaviors of teachers were found at the level of 0.05 regarding to gender, age, school location, and instructional level, all of which correlate with the proposed hypothesis. Tables 4, 5, 6, and 7 present findings regarding the differences in self-leadership behaviors of teachers in terms of gender, age, school location, and instructional level, respectively. 
Table 4. Summary of the Independent Samples t- test for gender related to self-leadership behaviors of U.S. elementary teachers

\begin{tabular}{cccccccc}
\hline Gender & $\mathrm{N}$ & Mean & SD & Levene's Test & $\mathrm{T}$ & d.f. & Sig (2-tailed) \\
\hline Male & 52 & 3.57 & 0.97 & \multirow{2}{*}{0.0000} & $-2.615^{*}$ & 56.845 & 0.011 \\
Female & 314 & 3.93 & 0.56 & & & & \\
\hline
\end{tabular}

*significant at the 0.05 level.

The Fisher's LSD Test indicated that participants who were female had self-leadership behaviors significantly higher than those were male.

Table 5. Summary of one-way ANOVA for age related to self-leadership behaviors of U.S. elementary teachers

\begin{tabular}{cccccccc}
\hline Age & $\mathrm{N}$ & Mean & SD & F & d.f.1 & d.f.2 & Sig. \\
\hline 30 and Younger & 86 & 3.73 & 0.86 & & & & \\
$31-40$ & 81 & 3.83 & 0.58 & $3.17^{*}$ & 3 & 362 & 0.024 \\
$41-50$ & 87 & 3.92 & 0.58 & & & & \\
51 and Older & 112 & 4.01 & 0.52 & & & & \\
\hline
\end{tabular}

*significant at the 0.05 level.

The Fisher's LSD Test indicated that participants who were 51 years and older had self-leadership behaviors significantly higher than those 30 years and younger.

Table 6. Summary of one-way ANOVA for school location related to self-leadership behaviors of U.S. elementary teachers

\begin{tabular}{cccccccc}
\hline School location & $\mathrm{N}$ & Mean & SD & F & d.f.1 & d.f.2 & Sig. \\
\hline Urban & 115 & 3.72 & 0.84 & & & & \\
Suburban & 192 & 3.95 & 0.48 & $5.347^{*}$ & 2 & 363 & 0.005 \\
Rural & 59 & 3.98 & 0.64 & & & & \\
\hline
\end{tabular}

*significant at the 0.05 level.

The Fisher's LSD Test for school location indicated that participants who taught in suburban and rural locations had self-leadership behaviors significantly higher than those who lived in urban locations.

Table 7. Summary of one-way ANOVA for instructional level related to self-leadership behaviors of U.S. elementary teachers

\begin{tabular}{cccccccc}
\hline Instructional level & $\mathrm{N}$ & Mean & SD & F & d.f.1 & d.f.2 & Sig. \\
\hline Kindergarten & 60 & 3.63 & 0.95 & & & & \\
Grade 1 & 59 & 3.81 & 0.53 & & & & \\
Grade 2 & 54 & 4.05 & 0.56 & & & & \\
Grade 3 & 60 & 3.91 & 0.66 & $2.495^{*}$ & 6 & 359 & 0.022 \\
Grade 4 & 53 & 3.97 & 0.48 & & & & \\
Grade 5 & 43 & 3.91 & 0.57 & & & & \\
Grade 6 & 37 & 3.95 & 0.50 & & & & \\
\hline
\end{tabular}

*significant at the 0.05 level.

The Fisher's LSD Test indicated that participants who taught in kindergarten had significantly lower self-leadership behaviors than grades 1-6, and participants who taught in grade 1 had significantly lower self-leadership behaviors than grade 2 .

Hypothesis 3: It was estimated that there were statistically significant differences between Thai and U.S. elementary teachers in terms of their level of self-leadership behaviors. 
As indicated in table 8, it was found that in the overall level, and also in the dimension level there were no significant differences. Therefore, the comparative analysis findings in the level of overall and dimension were not supportive of the hypothesis. However, when considering the level of subscale it was found that Thai participants had self-leadership behaviors higher than U.S. participants in relation to self-reward, self-observation, and visualizing successful performance. On the other hand, U.S. participants had self-leadership behaviors higher than Thai participants in relation to self-cueing, and self-talk.

Table 8. Summary of the Independent Samples t-test for Thai and U.S. elementary teacher related to self-leadership behaviors

\begin{tabular}{lcccccc}
\hline \multirow{2}{*}{ Dimensions and subscales } & \multicolumn{2}{c}{ Thai elementary teachers } & U.S. elementary teachers & \multirow{2}{*}{ t } & \multirow{2}{*}{ Sig. (2 tailed) } \\
\cline { 2 - 5 } & Mean & SD & Mean & SD & & \\
\hline Behavior-focused strategies & 3.93 & 0.50 & 3.86 & 0.68 & 1.765 & 0.078 \\
Self-goal setting & 4.00 & 0.50 & 4.09 & 0.77 & -0882 & 0.060 \\
Self-reward & 3.61 & 0.97 & 3.01 & 1.26 & $7.213^{*}$ & 0.000 \\
Self-observation & 4.18 & 0.46 & 3.97 & 0.76 & $4.359^{*}$ & 0.000 \\
Self-cueing & 3.95 & 0.82 & 4.34 & 0.94 & $-6.139^{*}$ & 0.000 \\
Natural reward strategies: & 4.17 & 0.46 & 4.13 & 0.73 & 0.689 & 0.491 \\
Focusing thoughts on natural rewards & 4.17 & 0.46 & 4.13 & 0.73 & 0.689 & 0.491 \\
Constructive thought pattern strategies & 3.83 & 0.51 & 3.83 & 0.78 & -0.082 & 0.933 \\
Visualizing successful performance & 3.90 & 0.54 & 3.65 & 0.96 & $4.367^{*}$ & 0.000 \\
Self-talk & 3.65 & 0.90 & 3.87 & 1.03 & $-3.060^{*}$ & 0.002 \\
Evaluating beliefs and assumptions & 3.93 & 0.51 & 3.97 & 0.80 & -0.918 & 0.359 \\
Overall & 3.95 & 0.41 & 3.89 & 0.65 & 1.548 & 0.122 \\
\hline
\end{tabular}

*significant at the 0.05 level.

Hypothesis 4: It was estimated that selected demographic variables had a statistically significant correlation with self-leadership behaviors.

In the case of Thai elementary teachers, table 9 indicated that there were not statistically significant correlations between every selected demographic variable of teachers and their self-leadership behaviors. In the case of U.S. elementary teachers, it was found that there were correlations between 1) gender, and 2) geographical school region and self-leadership behaviors.

Table 9. Pearson chi-square among selected demographic variables towards self-leadership behaviors of Thai and U.S. elementary teachers

\begin{tabular}{lccccccccc}
\hline \multirow{2}{*}{ Selected demographic variables s } & \multicolumn{3}{c}{ Thai elementary teachers } & \multicolumn{3}{c}{ U.S. elementary teachers } \\
\cline { 2 - 10 } & Chi-square & d.f. & Sig. & Cramer's V & Chi-square & d.f. & Sig. & Cramer's V \\
\hline Gender & 0.545 & 2 & 0.761 & - & $18.479^{*}$ & 4 & 0.001 & 0.225 \\
Age & 3.435 & 4 & 0.488 & - & 5.108 & 6 & 0.530 & - \\
Highest degree & 1.012 & 2 & 0.603 & - & 3.952 & 3 & 0.267 & - \\
Years of experience & 6.824 & 4 & 0.145 & - & 2.221 & 4 & 0.695 & - \\
School size & 9.654 & 10 & 0.471 & - & 4.148 & 6 & 0.657 & - \\
School location & 6.848 & 6 & 0.335 & - & 2.931 & 4 & 0.569 & - \\
Geographical school regions & 3.541 & 4 & 0.472 & - & $24.177^{*}$ & 6 & 0.000 & 0.182 \\
Instructional level & 16.221 & 12 & 0.181 & - & 14.651 & 12 & 0.261 & - \\
\hline
\end{tabular}

*significant at the 0.05 level.

\section{Discussion}

\subsection{The Degree of Self-Leadership Behaviors of Thai and U.S. Elementary Teachers}

According to the research findings, it was found that at the overall level, the degree of self-leadership behaviors of Thai and U.S. elementary teachers was at a high level. In the case of Thai elementary school teachers, it can be explained that at present the trends of globalization and information technology are so influential in Thai society that Thailand is turning from an affiliate-oriented society into an achievement-oriented society, focusing on an 
industrial/modern/urban/democratic perspective (Sanrattana, 2010). In addition, the government and related agencies have focused more on teacher empowerment due to the effects of The National Education Act 1999 (amended in 2002), approach to educational reform round 1 (1999-2008) and round 2 (2009-2018) (Thai Ministry of Education, 2010). Teacher empowerment was also addressed in a joint statement from the ASEAN Education Ministers Meeting in August 2005 (ASEAN, 2005). Further evidence of the focus on the importance self-development of teachers and education administrators came from the results of the external quality assessment at the basic education level round 2 (2006-2010), conducted by Office of Standard and Education Quality Assessment (Office for National Education Standards and Quality Assessment, 2011. This was supported by studies of Sanrattana, Parkay, and Phanphruk (2003), Sanrattana (2003, 2009), Theparee (2008), and Khanma (2010).

Regarding U.S. elementary teachers, it can be explained that the United States is an achievement-oriented society that values respect for others, personal responsibility, freedom to express ideas, and creativity, with a goal toward successful achievement. In terms of administrative style, leaders and followers cooperate in the planning and distribution of work, integrating the concepts of capability, cooperation and assessment, decentralization, and the establishment of permanent working groups (Sanrattana, 2010). These characteristics of the U.S. achievement-oriented society support the finding of a high level of self-leadership behaviors, which is a process through which people influence themselves to achieve the self-direction and self-motivation to behave and perform in desirable ways (Houghton \& Neck, 2006).

According to the research findings, it was found that Thai elementary teachers and U.S. elementary teachers were rated at the lowest level on the self-reward subscale. This may be explained by the effects of environment (Bronfenbrenner, 1986 cited in Sigelman \& Shaffer, 1995). More specifically, this concept states that from the past to the present, all countries in the world, including Thailand and U.S., have experienced economic depression, unemployment, and insufficient income. (Brezina, 2011) These problems were likely to cause the low level of self-reward as found for both Thai and U.S. elementary teachers, as compared to other variables.

4.2 To Compare Self-Leadership Behaviors of Thai and U.S. Elementary Teachers Regarding Gender, Age, Highest Degree, Years of Experience, School Location, School Size, Geographical School Regions, and Instructional Level

For Thai elementary teachers, it was found that there were significant differences at the 0.05 level based on two set variables; years of experience and school location. For years of experience, it was found that participants who had $0-10$ years of experience and those who had more than 20 years of experience had higher self-leadership than those who had 11-20 years of experience. This can be explained by the idea that teachers with 0-11 years of experience have more motivation to work because it is the beginning phase of their career according to the Incentive Theory of Hatch (2006). He stated that extrinsic motives such as environment, new experience, rewards, compliments, honors and acceptance all promote the motivation to work. However, he also stated that extrinsic motives do not sustain the motivated behaviors. When entering the high security phase of a career (11-20 years), the motivation for work as found earlier in 0-11 years is much more likely to decline. In contrast, when working more than 20 years or entering the $3 \mathrm{rd}$ phase of a career, the teachers had more self-leadership, compared to the 2 nd phase (11-20 years of working) because the teachers in the 3rd phase have a stable job and family. Therefore, teachers entering the 3rd phase of working are likely to develop themselves for social acceptance and success (Lavoie, 2002) based on Maslow's Hierarchy of Needs Theory (Kenrick, Griskevicius, Neuberg, \& Schaller, 2010). As a result, older teachers, including those who are close to retirement, have a higher motivation for further accreditation training than younger teachers (Thai Ministry of Education, 2009).

In relation to school location, it was found that participants who teach in suburban schools had self-leadership behaviors higher than rural participants. It can be hypothesized that suburban teachers derive social values from an urban community more than rural teachers. They are more competitive and active. Nevertheless, it was interesting to find that urban elementary teachers do not have higher self-leadership than the elementary teachers in suburban and rural areas. Further studies are required to clarify why the rural elementary teachers and the suburban elementary teachers have higher self-leadership than the urban elementary teachers.

In the case of U.S. elementary teachers, it was revealed that there were significant differences between self-leadership and each of four variables (gender, age, school location, and instructional level) based on the hypothesis. Regarding gender, it was found that females expressed self-leadership behaviors higher than males. This finding was validated by Northhouse (2010), who stated that women were somewhat more effective at leadership than men in education, government, and social service organizations. Correspondingly, Book (2000), Helgesen (1990), and Rosener (1995) indicated that women's leadership is more effective in contemporary society 
than men. Similarly, Eagly and Johnson (1990) found that women led in a more democratic, or participative, manner than men, reflecting a primary concept of self-leadership.

Regarding the age of the U.S. teachers, it was found that participants who were 51 and older had self-leadership behaviors higher than those who were 30 and younger. The reason was in line with the finding that Thai elementary teachers with more than 20 years of experience had more self-leadership behaviors than those with 11-20 years of experience. Similarly, U.S. elementary teachers of the same age as Thai elementary teachers had stable work and family, so they were determined to develop themselves for social acceptance and success in accordance with the Hierarchy of Needs Theory of Maslow (Kenric et al., 2010).

For school location, it was found that, as was true for Thai teachers, U.S. participants who lived in suburban and rural areas had self-leadership behaviors higher than those who lived in urban areas. This was a somewhat unexpected finding because people living in cities typically have more active and competitive lifestyles than people living in the countryside (Sanrattana, 2010) and might be expected to have more self-leadership, too. Therefore, further research should be conducted to further study the phenomenon of self-leadership among teachers who work in different locations (urban, suburban and rural).

In terms of instructional levels, it was found that participants who taught in kindergarten had the lowest self-leadership behaviors of elementary teachers at all levels. Participants who taught in grade 2 had higher self-leadership behaviors than grade 1. It can be explained that kindergarten teachers, considered the lowest instructional level, had low self-leadership behaviors because they believed that their responsibility for their young students did not require much self-leadership behaviors. That was in line with the finding that teachers of grade 2 students had more self-leadership behaviors than teachers teaching grade 1 students, whose maturity and age are lower than grade 2 students.

\subsection{Comparison of Self-Leadership Behaviors of Thai and U.S. Teachers}

In comparing the self-leadership behaviors of Thai and U.S. elementary teachers, it was found that there were no significant differences as a whole and in each dimension of variables. This finding did not support the hypothesis. It can be explained in line with the earlier finding that the global awareness of self-leadership development, like educational reform, is influential in many countries. Thailand and the U.S. are both promoting educational reform. Another reason was that the variables and indicators used in this research were international and were guidelines for teacher development in both Thailand and the U.S. Ratchapat (2011) stated that factors of teacher leadership for Thai teacher development consisted of stimulating potential to have a vision for self-development, self-confidence, self-training, self-trust, and self-management. The data analysis was in line with the universal visions of many western scholars who have studied teacher leadership development (e.g. Zepeda, Mayers, \& Benson, 2003; Beach, 2006; Reeves, 2006; Smith \& Piele 2006; English, 2008; Robertson, 2008; Beerel, 2009; Davies, 2009; Chance, 2009; Macbeath \& Demster, 2009; Kowalski, 2010; Leithwood, Harris, \& Strauss, 2010; Northouse, 2010, 2012; Bryman, Collinson, Grint, Jackson, \& Uhi-Bien, 2011; Hilty, 2011) Worldwide interest in these topics is further enhanced by the availability of information technology that is easily accessible from everywhere and supports the international sharing of research results and professional development models.

In regard to subscale, it was found that Thai participants had a higher level of self-leadership behaviors than U.S. participants in relation to self-reward, self-observation and visualizing successful performance. For self-reward, this finding can be explained based on cultural and sociological aspects. Thai people love fun and celebrations on any occasion. They enjoy going to parties to celebrate birthdays, new houses, ordinations, anniversaries, and job promotions. Celebrations in Thailand also extend to those of other nations (Wirachanipawan, 2004). Additionally, Thai people are good consumers and tend to be fashion conscious. (Thai Wisdom Bank Project, 2006) Such social values were seen by Thai people as well as Thai teachers as "self-rewarding," rather than considering success related to work in this category. In contrast, U.S. people are serious about work, and they reward themselves when they succeed in their career (Sanrattana, 2010). Given their definition of rewards, Thai elementary teachers had self-reward more often than U.S. elementary teachers.

In regard to self-observation, Thai participants had a higher level of self-leadership behaviors than U.S. participants due to the influence of Buddhist doctrines. Buddhist psychology and self-development in Thailand support personal development by the use of self-observation techniques, such as practicing meditation and enhancing consciousness and awareness (Silva, 1990; Srikhruedong, 2010). In regards to visualizing successful performance, Thai participants had higher self-leadership behaviors than U.S. participants because Thailand has a policy for educational quality assurance based on the National Education Act 1999 (amended in 2002). This educational quality assurance is conducted both internally and externally in order to develop all instructional levels, and is considered a part of Thai education administration. It is always conducted and reported for 
publication at least once every five years (Wattananikorn, 2011). The present Thai education administration has used result-based management or RBM widely in schools (Sanrattana, 2010). In short, according to the research finding, Thai elementary teachers had significantly more visualizing successful performance than U.S. elementary teachers.

In regard to the finding that U.S. participants had higher self-leadership behaviors than Thai participants in relation to self-cueing and self-talk, Sanrattana (2010) explained that U.S. people tend to focus on individualism, are serious about their careers, and are determined to develop themselves for a better future. These social values are reasons why U.S. elementary teachers have self-talk and self-cueing at a higher level than Thai elementary teachers. In comparison, Thai teachers are easygoing, enjoy life, and are fashion conscious. Therefore, they tend to focus on shorter rather than long-term goals, seldom use self-talk for self-improvement, and do not tend to plan for the future.

\subsection{Correlation Between Selected Demographic Variables and Self-Leadership Behaviors of Thai and U.S. Elementary Teachers}

According to the research findings, none of the selected demographic variables (gender, age, highest degree, years of experience, school size, school location, geographical school region, and instructional level) involving Thai elementary teachers indicated any significant correlation toward self-leadership behaviors. This is because all groups of Thai elementary teachers develop themselves using internal and external stimulation. Internal stimulation factors include alertness to changing trends, acceptance, and successful work. External stimulation factors include policy measures from all organizational levels, educational quality assurance, and promotion and accreditation guidelines. (Thai Ministry of Education, 2010; Office for National Education Standards and Quality Assessment, 2011)

According to the finding of self-leadership of the U.S. elementary teachers, it was found that gender and geographical school region showed significant correlation with self-leadership behaviors as the set hypothesis. In terms of gender, variance can be explained by the fact that there are fewer U.S. women in leadership positions than men. As one example of this, although women in 2009 were among the leadership ranks in American organizations, occupying more than half of all management and professional positions (50.8\%) (Catalyst, 2009) and nearly a quarter of all CEO positions (23.4\%) (U.S. Bureau of Labor Statistics, 2008) this was much less true in more elite leadership positions. For example, women represent $3 \%$ of Fortune $500 \mathrm{CEO}$, and hold only $15.2 \%$ of the Fortune 500 board seats and $15.7 \%$ of the Fortune 500 corporate officer positions (Catalyst, 2009). As another example, in 2009 women held only 90 of the 535 seats in the U.S. Congress (16.8\%; $17 \%$ in the Senate and $16.8 \%$ in the House of Representatives); women of color occupied just 20 seats (Center for American Woman and Politics, 2009). Also the U.S. data for this research included just 52 males, representing $14.2 \%$ of the total sample, and 314 females, representing $85.8 \%$. All of these facts provide evidence that support the correlation of gender and self-leadership behaviors of U.S. elementary teachers.

In terms of geographical school regions, the U.S. has a variety of cultures and is a big country, so teachers living in different zones have different lifestyles, values and cultures. For example, teachers living in the North and those living in the South do not follow the same education policies. Each state has own set of educational policies. These differences affect the variant of geographical school regions.

\section{Recommendations}

1) All the education stakeholders should promote self-leadership of Thai and U.S. elementary teachers on a regular basis. This is because levels of self-leadership depend on many factors, including both internal and external factors. Without attention and surveillance for professional development, self-leadership can decline.

2) To develop self-leadership, Thai and U.S. teachers should pay more attention to self-reward because the findings revealed that self-reward was low, compared to the other variants. This is especially true for U.S. teachers, whose self-reward was only at an "average" level. Moreover, according to the findings, U.S. elementary teachers were found to have significantly lower self-reward than their Thai counterparts.

3) In the case of Thai elementary teacher development, teachers in rural locations and teachers who have 11-20 years of experience should be of special concern because the findings revealed that Thai elementary teachers in these groups have self-leadership significantly lower than other groups.

4) In the case of U.S. elementary teacher development, teachers who are male, teachers who are less than 30 years old, teachers who live in urban locations, and teachers who teach at the kindergarten level should be of particular concern because the findings revealed that U.S. elementary teachers in these groups had 
significantly lower self-leadership than other groups.

5) Buddhist teachings about concentration and consciousness should be applied to U.S. teachers to develop self-observation as Thai teachers do. The process of "practicing meditation", for example, could be conducted with U.S. teachers to help them develop their self-observation skills.

6) The advantages of U.S. social values like dedication to work, critical thinking, rationality, planning, and individualism should be applied to Thai teachers to develop self-cueing and self-talking skills.

7) U.S. elementary teachers should employ intensive educational assessment as Thai teachers do to improve visualized successful performance. Data revealed that U.S. elementary teachers had visualized successful performance at a level lower than Thai teachers. Although the U.S. is an achievement-oriented society, Thai teachers have more visualized successful performance because the Thai education system emphasizes the use of intensive education assessment as well as result-based management.

8) Planning to develop self-leadership for Thai elementary teachers in the future can be conducted as a program that can be generalized because the research findings revealed that all the variants were found to have no significant correlation with self-leadership. On the other hand, research regarding U.S. elementary teachers needs to elaborate on gender and geographical school regions because the findings revealed that both of these variants indicated significant correlation with self-leadership.

\section{Acknowledgements}

The author thanks to the Thailand Research Fund through the Royal Golden Jubilee Ph.D. Program, Office of the Higher Education Commission and the Graduate School Khon Kaen University, Thailand for grant.

\section{References}

Anderson, J. S., \& Prussia, G. E. (1997). The self-leadership questionnaire: Preliminary assessment of construct validity. The Journal of Leadership Studies, 4(2), 119-143. https://doi.org/10.1177/107179199700400212

Andrews, D., \& Crowther, F. (2002). Parallel leadership: A clue to the content of the "black box" of school reform. International Journal for Educational Management, 16(4), 152-159. https://doi.org/10.1108/09513540210432128

ASEAN. (2005). Statement of the Ministers responsible for education of ASEAN countries. Bangkok.

Beach, L. R. (2006). Leadership and the art of change: A practical guide to organizational transformation. Thousand Oaks, CA: Sage.

Beerel, A. (2009). Leadership and change management. Thousand Oaks, CA: Sage.

Book, E.W. (2000). Why the best man for the job is a woman. New York: HarperCollins.

Brezina, C. (2011). America's recession: The effects of the economic downturn (headlines!). New York: Rosen Classroom.

Brislin, R. W. (1986). The wording and translation of research instruments. In W. J. Lonner, \& J. W. Berry (Eds.), Field methods in cross-cultural research (pp. 137-164). Beverly Hills: Sage Publications.

Bronfenbrenner, U. (1986). Ecology of the family as a context of human.

Bryman, A., Collinson, D., Grint, K., Jackson, B., \& Uhi-Bien, M. (Eds). (2011). The SAGE handbook of leadership. Thousand Oaks, CA: Sage.

Catalyst. (2009). Statistical overview of woman in the workplace. Retrieved from http://www.catalyst.org/file/172/qt_statistical_overview_of_women_in_the_workplace.pdf

Center for American Woman and Politics. (2009). Women in elective office 2009. Retrieved from http://www.cawp.rutgers.edu/fast_facts/levels_of_office/documents/elective.pdf

Center for Creative leader. (2019). The leadership development roadmap. Retrieved from http://www.ccl.org/

Chance, P. L. (2009). Introduction to educational leadership and organizational behavior: Theory and practice. San Francisco: Jossey-Bass.

Coleman, J. S. (1988). Social capital in the creation of human capital. American Journal of Sociology, 94(Supplement), 95-120.

Crowther, F., \& Olsen. (1997). Teachers as leaders-an exploratory framework. International Journal of Educational Management, 11(1), 6-13. 
Davies, B. (2009). The essentials of school leadership (2nd ed.). Thousand Oaks, CA: Sage.

Eagly, A. H., \& Johnson, B. T. (1990). Gender and leadership style: A meta-analysis. Psychological Bulletin, 108(2), 233-256. https://doi.org/10.1037/0033-2909.108.2.233

English, F. W. (2008). The art of educational leadership: Balancing performance and accountability. Thousand Oaks, CA: Sage.

Gamoran, A., Anderson, C. W., Quiroz, P. A., Secada, W. G., Williams, T., \& Ashmann, S. (2003). Transforming teaching in math and science: How schools and districts can support change. New York: Teachers College Press.

Harris, A., \& Muijs, D. (2005). Improving schools through teacher leadership. Maidenhead: Open University Press.

Hatch, M. J. (2006). Organization theory: Modern, symbolic, and postmodern perspectives (2nd ed.). New York: Oxford University Press.

Helgesen, S. (1990). The female advantage: Women's ways of leadership. New York: Doubleday.

Hilty, E. B. (editor). (2011). Teacher leadership: The new foundations of teacher education. New York: Peter Lang.

Houghton, J. D., \& Neck, C. D. (2002). The revised self-leadership questionnaire: testing hierarchical factor structure of self-leadership. Journal of Managerial Psychology, 17(8), 672-691. https://doi.org/10.1108/02683940210450484

Joshi, S. (2019). Self Leadership. Retrieved March 29th, 2019, from https://pt.slideshare.net/p4sl/the-discipline-of-self-leadershipptx/5

Katzenmeyer, M., \& Moller, G. (2001). Awakening the sleeping giant: Helping teachers develop as leaders (2nd ed.). Thousand Oaks, CA: Corwin Press.

Kenrick, D. T., Griskevicius, V., Neuberg, S. L., \& Schaller, M. (2010). Renovating the pyramid of needs: Contemporary extensions built upon ancient foundations. Perspectives on Psychological Science, 5(3), 292-314. https://doi.org/10.1177/1745691610369469

Khanma, B. (2010). Teacher perception of self-leadership for elementary school principals in Thailand: Strategies of behavior-focused, natural Rewards, and constructive thought patterns. Educational Administration Journal, Khon Kaen University, 6(1), 61-66.

Kowalski, T. J. (2010). The school principal: Visionary leadership and competent management. New York: Routledge.

Krejcie, R. V., \& Morgan, D. W. (1970). Determining sample size for research activities. Educational and Psychological Measurement, 30(3), 607-610. https://doi.org/10.1177/001316447003000308

Lavoie, R. D. (2002). The teacher role in developing skills. Retrieved from http://www.ricklavoie.com/teacherart.html

Leithwood, K., \& Riehl, C. (2005). What we know about successful school leadership. In W. Firestone, \& C. Riehl (Eds.), A new agenda: Directions for research on educational leadership (pp. 12-27). New York: Teachers College Press. https://doi.org/10.1007/978-1-4020-6022-9_4

Leithwood, K., Harris, A., \& Strauss, T. (2010). Leading school turnaround: How successful leaders transform low-performance schools. San Francisco: Jossey-Bass.

Lord, B., \& Miller, B. (2002). Teacher leadership: An appealing and inescapable force in school reform? Education Development Center, Newton, MA .

Macbeath, J., \& Demster, N. (Eds.) (2009). Connecting leadership and learning: Principles for practice. New York: Routledge.

Manz, C. C., \& Neck, C. P. (2004). Mastering self-leadership: Empowering yourself for personal excellence (3rd ed.). Upper Saddle River, NJ: Prentice Hall.

Manz, C. C., \& Sims, H. P., Jr. (1980). Self-management as a substitute for leadership: A social learning perspective. Academy of Management Review, 5, 361-367. https://doi.org/10.5465/amr.1980.4288845

Manz, C. C., \& Sims, H. P., Jr. (2001). The new super leadership: Leading others to lead themselves. San Francisco, Berrett-Koehler. 
Midlock, S. F. (2011). Case studies for educational leadership: Solving administrative dilemmas. Boston: Pearson.

Neck, C. P., \& Houghton, J. D. (2006). Two decades of self-leadership theory and research: Past developments, present trends, and future possibilities. Journal of Managerial Psychology, 21(4), 270-295. https://doi.org/10.1108/02683940610663097

Neck, C. P., \& Manz, C. C. (1992). Thought self-leadership: The impact of self-talk and mental imagery on performance. Journal of Organizational Behavior, 12, 681-699. https://doi.org/10.1002/job.4030130705

Neck, C. P., Stewart, G., \& Manz, C. C. (1995). Thought self-leadership as a framework for enhancing the performance of performance appraisers. Journal of Applied Behavioral Science, 31, 278-302. https://doi.org/10.1177/0021886395313004

Northouse, P. G. (2010). Leadership: Theory and practice (5th ed.). Thousand Oaks, CA: Sage.

Northouse, P. G. (2012). Introduction to Leadership: Concept and Practice (2nd ed.). Thousand Oaks, CA: Sage.

Office for National Education Standards and Quality Assessment. (2011). Annual report 2008. Retrieved from http://www.onesqa.or.th/th/ download/index.php?SystemMenuID=1\&SystemModuleKey=9

Ogawa, R., \& Bossert, S. (1995). Leadership as an organizational quality. Educational Administration Quarterly, 31, 224-243. https://doi.org/10.1177/0013161x95031002004

Prussia, G. E., Anderson, J. S., \& Manz, C. C. (1998). Self-leadership and performance outcomes: The mediating influence of self-efficacy. Journal of Organizational Behavior, 19, 523-538. https://doi.org/10.1002/(sici)1099-1379(199809)19:5<523::aid-job860>3.0.co;2-i

Ratchapat, A. (2011). A development of teacher leadership indicators for basic education school (Doctoral Dissertation in Educational Administration, The Graduate School, Khon Kaen University).

Reeves, D. B. (2006). The learning leader: How to focus school improvement for better results. Alexandria, Virginia: ASCD.

Robertson, J. (2008). Coaching educational leadership: Building leadership capacity through partnership. Thousand Oaks, CA: Sage. https://doi.org/10.4135/9781446221402

Rosener, J. (1995). American competitive secret: Utilizing women as a management strategy. New York: Oxford University Press.

Sanrattana, W. (2003). Conditions for change in small-sized primary schools. Teacher Education, Khon Kaen University, 27(1), 44-57.

Sanrattana, W. (2009). New school principals in Thailand: Influences on their leadership and professional development. Presented at the AERA annual meeting 2009 at San Diego, CA. U.S.A. April 13-17, 2009.

Sanrattana, W. (2010). School Principal: Tri-dimensions of effective professional development. Khon Kaen: Klangnana Witaya.

Sanrattana, W., Parkay, F. W., \& Samphan, P. (2003). Beginning primary-school principals in Thailand: A national survey of their priorities and concerns. Presented at the Annual Meeting of the American Educational Research Association (AERA), Chicago, U.S.A. April, 21, 2003

Sigelman, C. K., \& Shaffer, D. R. (1995). Life-span development (2nd ed.). Pacific Grove..

Silva, D. Y., Gimbert, B., \& Nolan, J. (2000). Sliding the doors: Locking and unlocking possibilities for teacher-leadership. Teachers College Record, 102(4), 779-804. https://doi.org/10.1111/0161-4681.00077

Silva, P. (1990). Buddhist psychology: A review of theory and practice. Current Psychology, 9(3), 236-254.

Smith, S. C., \& Piele, P. K. (2006). School leadership: Handbook for excellence in student learning (4th ed.). Thousand Oaks, CA: Sage.

Smylie, M. A., Conley, S., \& Marks, H. M. (2002). Exploring new approaches to teacher leadership for school improvement. In J. Murphy (Ed.), The educational challenge: Redefining leadership for the 21st century (pp. 162-188). Chicago: University of Chicago Press. https://doi.org/10.1111/j.1744-7984.2002.tb00008.x

Spillane, J. P. (2004). School leadership in practice: A distributed perspective. Paper presented at the Gerald Ford School of Public Policy, University of Michigan. Ann Arbor, MI.

Spillane, J., \& Thompson, C. (1997). Reconstructing conceptions of local capacity: The local education agency's capacity for ambitious instructional reform. Educational Evaluation and Policy Analysis, 19(2), 185-203. 
https://doi.org/10.3102/01623737019002185

Spillane, J., Halverson, R., \& Diamond, J. (2004). Towards a theory of school leadership practice: Implications of a distributed perspective. Journal of Curriculum Studies, 36(1), 3-34. https://doi.org/10.1080/0022027032000106726

Srikhruedong, S. (2010). A study the relations between administrations'leadership and perception towards and academic administrative effectiveness in Buddhist University. Department of Psychology, Faculty of Humanities, Mahachulalongkornrajavidyalaya University

Thai Ministry of Education. (2009). National educational policy 2009. Retrieved from http://www.moe.gov.pk/nepr/NEP_2009.PDF

Thai Ministry of Education. (2010). Education Ministry Accelerates Teacher Development in Order to Achieve Second Decade of Education Reform. Retrieved from http://www.en.moe.go.th/index.php?option=com content\&view=article\&id=353:education-ministry-accelerates-teacher-development-in-order-to-achieve-sec ond-decade-of-education-reform\&catid $=1$ :news\&Itemid $=42$

Thai Wisdom Bank Project. (2006). Value of current Thai society. Retrieved from http://www.panyathai.or.th/

Theparee, P. (2008). A Study of Self Development of the Kindergarten Teachers in Private Schools, Bangkok (Master of Education Degree in Educational Administration, Srinakharinwirot University).

U.S. Bureau of Labor Statistics. (2008). Current population survey, annual averages: House hold data (Table 11: Employed persons by detailed occupation, sex, race, and Hispanic or Latino ethnicity). Retrieved from http://www.bls.gov/cps/cosaat 11.pdf

Uchida, T. (2019). Self Leadership "Leadership Within Yourself". Retrieved from https://www.slideshare.net/followdream/self-leadership-and-strategy-presentation?type=powerpoint

Wattananikorn, K. (2011). Quality assurance in Thailand is carried out under Chapter 6 of the National Education Act. 1999. Retrieved http://www.aunsec.org/site/main/web/index.php?option=com_content\& view $=$ section\&id $=32 \&$ Itemid $=187 \&$ lang $=$ en

Wirachanipawan, W. (2004). The Thai value in the age of bureaucratic reforming. Bangkok: Pro Press.

York-Barr, J., \& Duke, K. (2004). What do we know about teacher leadership? Findings from two decades of scholarship. Review of Educational Research, 74(3), 255-316. https://doi.org/10.3102/00346543074003255

Zepeda, S. J., Mayers, R. S., \& Benson, B. N. (2003). The call to teacher leadership. San Francisco: Jossey-Bass.

\section{Copyrights}

Copyright for this article is retained by the author(s), with first publication rights granted to the journal.

This is an open-access article distributed under the terms and conditions of the Creative Commons Attribution license (http://creativecommons.org/licenses/by/4.0/). 